\title{
Prevalence and pattern of familial disease in primary biliary cirrhosis
}

\author{
A M Brind, G P Bray, B C Portmann, Roger Williams
}

\begin{abstract}
Susceptibility to primary biliary cirrhosis (PBC) may be partly inherited although instances of PBC within families are only infrequently described. The records of 736 patients with PBC seen over a 25 year period were examined to identify those with a positive family history. Ten patients originating from eight families were identified, giving a frequency of $1 \cdot 33 \%$. They comprised mother and daughter pairs; in two families both mother and daughter had been seen at our clinic. The daughters presented at an earlier age, median 36 years (range 24-54), than the mothers, 52 years (50-81). During follow up one daughter (45 years) and six mothers have died (range 53-81 years) and two mothers and one daughter have had a transplant aged 57, 57, and 30 years respectively. It is concluded that familial PBC is not rare, that it is related to maternally inherited factors, and that disease tends to present earlier in the second generation.
\end{abstract}

(Gut 1995; 36: 615-617)

Keywords: familial disease, primary biliary cirrhosis.

Primary biliary cirrhosis (PBC) is considered to be an autoimmune disease as it is associated with serum anti-mitochondrial antibodies and abnormalities of the immune system. Although it is not thought to be an inherited disease, there have been a number of reports describing multiple cases of $\mathrm{PBC}$ occurring within a single family. ${ }^{1-17}$ However, there has only been one recent systematic study of PBC frequency within families published as an abstract. ${ }^{18}$

Abnormalities of immune function have also been shown in family members of patients with PBC suggesting immunogenetic susceptibility. Unaffected family members have an increased frequency of anti-mitochondrial antibodies 4 and abnormal $\mathrm{T}$ cell function. ${ }^{16} 19$ The exact nature of the molecular basis for an inherited immunological susceptibility to PBC and its comparative importance to disease manifestation remains uncertain.

The evidence that environmental factors are important in the development of PBC is limited $^{2021}$ but such factors could also be involved in its familial occurrence.

In this report, we describe a systematic study of 736 patients with PBC who attended and were reviewed over a period of 25 years in a single unit, carried out to determine both the prevalence and pattern of familial disease.

\section{Methods}

The case records of a total of 736 patients who were referred to and reviewed at the Institute of Liver Studies, King's College Hospital from 1967 to 1992 with an established diagnosis of PBC were examined to identify those with a record of other cases of PBC within the family. The diagnosis of PBC was based on standard criteria (that is, positive anti-mitochondrial antibody, raised biliary enzymes, compatible clinical history, and liver histology). Details of presentation (mode, date, and age), autoantibodies, liver biopsy findings, follow up and outcome, presence of other diseases and family history of autoimmune disease were obtained wherever possible by interview or by informal postal questionnaire of the patients and affected family, as well as examining the case records held within our hospital and any other hospitals attended by the patient.

\section{Results}

In $10(1.33 \%)$ of 736 patients there was a history of PBC in a family member and in two instances both affected family members had been seen at our clinic. Table I gives details of the patients, and the first patient to be seen. All had serum anti-mitochondrial antibody positivity and were mother and daughter pairs, all were white and originated from Britain. No record of affected but unrelated family members was found. All mothers and two of the daughters were cirrhotic at diagnosis; the histological stage of disease and the date of liver biopsy is shown. The daughters presented at an earlier age, median 36 years (range 24-54) than the mothers, median 52 years (range 50-81). All but three of the daughters had presented before their mothers.

Of the eight affected daughters, three were asymptomatic at presentation and were diagnosed because of the finding of abnormal liver function tests. Three others had presented with jaundice in pregnancy, one with tiredness, and one with bleeding oesophageal varices. All the mothers were symptomatic at presentation: two had tiredness, two abdominal pain, one jaundice, and three oesophageal varices. Although all the daughters had been raised by their mothers, at the time of presentation none of the daughters was living with her mother. There were records of associated thyroid disease in three patients and one had coeliac disease.

Median follow up for the daughters was 6.5 years (range $2-16$ ) and for the mothers was 3.5 years (range 1 month-9 years). Mortality over this period comprised one daughter (aged 45 years) and six mothers, median age 72 years 
TABLE I Clinical details of familial cases of primary biliary cirrhosis

\begin{tabular}{|c|c|c|c|c|c|c|c|}
\hline Family & Presentation & Date & Age & $\begin{array}{l}\text { Biopsy stage } \\
\text { and date }\end{array}$ & $\begin{array}{l}\text { Serum } \\
\text { autoantibodies }\end{array}$ & $\begin{array}{l}\text { Autoimmune } \\
\text { disease }\end{array}$ & $\begin{array}{l}\text { Follow up and } \\
\text { outcome }\end{array}$ \\
\hline $\begin{array}{l}1 \text { Daughter* } \\
\text { Mother } \\
2 \text { Daughter }\end{array}$ & $\begin{array}{l}\text { Jaundice in pregnancy } \\
\text { Abdominal pain } \\
\text { Abnormal LFTs }\end{array}$ & $\begin{array}{l}1986 \\
1986 \\
1988\end{array}$ & $\begin{array}{l}24 \\
51 \\
51\end{array}$ & $\begin{array}{ll}\text { II } & 1989 \\
\text { III } & 1987 \\
\text { I } & 1990\end{array}$ & $\begin{array}{l}\text { AMA } 1 / 320 \\
\text { AMA } 1 / 320 \\
\text { AMA } 1 / 160 \\
\text { ANA } 1 / 10\end{array}$ & $\begin{array}{l}\text { Nil } \\
\text { Thyroid disease } \\
\text { Nil }\end{array}$ & $\begin{array}{l}\text { Asymptomatic } \\
\text { Transplanted } 1992 \\
\text { Asymptomatic }\end{array}$ \\
\hline 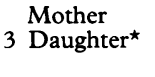 & $\begin{array}{l}\text { Abdominal pain } \\
\text { Jaundice in pregnancy }\end{array}$ & $\begin{array}{l}1961 \\
1985\end{array}$ & $\begin{array}{l}51 \\
25\end{array}$ & $\begin{array}{ll}\text { IV } & 1972 \\
\text { III } 1986\end{array}$ & $\begin{array}{l}\text { AMA + } \\
\text { AMA } 1 / 40 \\
\text { ANA } 1 / 160\end{array}$ & $\begin{array}{l}\text { Thyroid disease } \\
\text { Nil }\end{array}$ & $\begin{array}{l}\text { Died liver disease } 1972 \\
\text { Transplanted } 1991\end{array}$ \\
\hline $\begin{array}{l}\text { Mother } \\
4 \text { Daughter } \\
\text { Mother }\end{array}$ & $\begin{array}{l}\text { Jaundice } \\
\text { Fatigue } \\
\text { Variceal bleed }\end{array}$ & $\begin{array}{l}1984 \\
1976 \\
1988\end{array}$ & $\begin{array}{l}50 \\
38 \\
73\end{array}$ & $\begin{array}{ll}\text { IV } & 1985 \\
\text { IV } & 1976 \\
\text { IV } & 1988\end{array}$ & $\begin{array}{l}\text { AMA }+ \\
\text { AMA } 1 / 640 \\
\text { AMA } 1 / 640 \\
\text { ANA } 1 / 20\end{array}$ & $\begin{array}{l}\text { Nil } \\
\text { Nil } \\
\text { Nil }\end{array}$ & $\begin{array}{l}\text { Transplanted and died } 1987 \\
\text { Ascites and varices } 1982 \\
\text { Died variceal bleed } 1988\end{array}$ \\
\hline 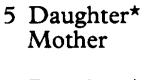 & $\begin{array}{l}\text { Abnormal LFTs } \\
\text { Fatigue }\end{array}$ & $\begin{array}{l}1976 \\
1983\end{array}$ & $\begin{array}{l}33 \\
70\end{array}$ & $\begin{array}{ll}\text { II } & 1984 \\
\text { IV } & 1983\end{array}$ & $\begin{array}{l}\text { AMA + } \\
\text { AMA } 1 / 800 \\
\text { SMA + }\end{array}$ & $\begin{array}{l}\text { Coeliac disease } \\
\text { Nil }\end{array}$ & $\begin{array}{l}\text { Varices } 1990 \\
\text { Died liver disease } 1990\end{array}$ \\
\hline $\begin{array}{l}6 \text { Daughter } \\
\text { Mother } \\
7 \text { Daughter } \\
\text { Mother } \\
8 \text { Daughter* } \\
\text { Mother }\end{array}$ & $\begin{array}{l}\text { Variceal bleed } \\
\text { Variceal bleed } \\
\text { Abnormal LFTs } \\
\text { Variceal bleed } \\
\text { Jaundice in pregnancy } \\
\text { Fatigue and pruritus }\end{array}$ & $\begin{array}{l}1976 \\
1971 \\
1989 \\
1991 \\
1985 \\
1988\end{array}$ & $\begin{array}{l}43 \\
69 \\
54 \\
81 \\
29 \\
53\end{array}$ & $\begin{array}{l}\text { IV } 1976 \\
\text { IV } 1971 \\
\text { II } 1989 \\
\text { No biopsy } \\
\text { III } 1992 \\
\text { Incomplete } \\
\text { details }\end{array}$ & $\begin{array}{l}\text { AMA } 1 / 320 \\
\text { Not tested } \\
\text { AMA } 1 / 1290 \\
\text { AMA } 1 / 320 \\
\text { AMA + } \\
\text { AMA + }\end{array}$ & $\begin{array}{l}\text { Nil } \\
\text { Raynauds } \\
\text { Polyarthritis } \\
\text { Thyroid disease } \\
\text { Nil } \\
\text { Nil }\end{array}$ & $\begin{array}{l}\text { Died liver disease } 1978 \\
\text { Died liver disease } 1971 \\
\text { Asymptomatic } \\
\text { Died liver disease } 1991 \\
\text { Mild symptoms } \\
\text { Mild symptoms }\end{array}$ \\
\hline
\end{tabular}

${ }^{\star}$ First case seen. $\mathrm{LFT}$ = liver function tests, AMA=anti-mitochondrial antibodies.

(range 53-81). Two mothers and one daughter have had a transplant because of deterioration in liver function with serum bilirubin rising to $>250 \mu \mathrm{M}$. This was at age 57 years in two cases and age 30 years in the third (six, three, and seven years after presentation respectively). Three daughters remained virtually asymptomatic over the follow up period, one has mild symptoms, and three daughters have bled from oesophageal varices.

\section{Discussion}

Familial primary biliary cirrhosis is not rare although the frequency of $1.33 \%$ recorded in our series is, however, less than the 5.5\% (22 of 405) reported in the one previous study, which was carried out in New York. ${ }^{18}$ Our figure for prevalence may be an underestimate as ascertainment depended on the index case being aware of the medical history of their relatives and a record of this appearing in the case notes. It is unlikely that the discrepancy between the two studies results from differences in the criteria used for diagnosis, 38 patients with undiagnosed liver disease are mentioned in the other report but are not included in their calculation of PBC prevalence. We were strict in excluding cases where a diagnosis of PBC was not definite and many of our cases were followed up for a considerable period. Our series does not

TABLE II Case reports of familial PBC

Walker et al $1972^{1}$
Klatskin et al $1972^{2}$
Chohan et al $1973^{3}$
Galbraith et al $1974^{4}$
Tong et al $1976^{5}$
Fagan et al $1977^{6}$
Douglas et al $1977^{7}$
Jaup et al $1980^{8}$
Kato et al $1981^{9}$
Cales et al $1983^{10}$
James et al $1986^{11}$
Chiaranti et al $1987^{12}$
Chalmers et al $1987^{13}$
James and Myszor $1990^{14}$
Manns et al $1991^{15}$
Tsuji et al $1962^{16}$
Harada et al $1992^{17}$

2 Sisters
2 Sisters
Twin sisters
Two brothers
Mother and daughter
Mother and daughter
Mother and daughter with coincident onset and disease in
non-related carer
Father and 4 daughters associated with hypergammaglobulinaemia
Father and daughter
2 Brothers with common HLA haplotype
Father and daughters associated with IgA deficiency
Mother and 2 daughters
2 Sisters associated with autoimmune thrombocytopenia
2 Mother and daughter pairs
2 Sisters, mother and daughter with common HLA-1 haplotype
2 Sisters, brother and sister with similar T cell responsiveness
Brother and sister associated with polymositis, Hashimoto's
thyroiditis, and vasculitis

include any families with more than two affected members whereas seven such families are described in the other study. In that report, it was suggested that the occurrence of multiple family members with PBC might result from increased penetrance of the disease or increased awareness of the disease in the affected family. The higher prevalence recorded in the other group may be because of greater disease awareness and more frequent screening for disease in their population, or result from a real difference in the comparative importance of familial factors in the aetiology of PBC in these two parts of the world.

The familial predisposition that undoubtedly exists in PBC may have a genetic or environmental background. Published reports afford considerable evidence for a genetic predisposition. Thus there are the reports of HLA associations: with C4B2, 22 C4A-Q0, ${ }^{15}$ and $\mathrm{DR} 8^{1523}$ and we have found in other studies carried out in this Institute that $11 \%$ of patients have the HLA DR8-DQB $1{ }^{\star} 0402$ haplotype. ${ }^{23}$ There have also been reports of associations with a restriction fragment polymorphism within the tumour necrosis factor gene $^{24}$ and the $\mathrm{B}$ related transcript gene. ${ }^{25}$ These genotypic associations may underly the phenotypic findings of abnormal lymphocyte function in families with PBC. ${ }^{16}$ None of our cases of familial PBC was associated with a well defined immune disorder, unlike those previously described in association with IgA deficiency $^{11}$ or hypergammaglobulinaemia. $^{8}$

Table II gives a summary of previous reports of familial cases of PBC. All our cases were female, which is consistent with the female preponderance in PBC, although affected male family members have been reported. Inheritance was maternal as in all other reported cases where it is possible to deduce inheritance; the one exception was in the family with associated hypergammaglobulinaemia (father and daughters). ${ }^{11}$ If the inherited predisposition to PBC is truly maternal it might involve mitochondrial DNA, which is always maternally inherited or be related to non-inherited maternal HLA antigens, which have been implicated in the familial predisposition to rheumatoid 
arthritis. ${ }^{26}$ Inherited familial predisposition to PBC is more likely, however, to be complex and polygenic involving the interaction of a number of genes.

With respect to an environmental basis for the familial occurrence of PBC, epidemiological studies have linked development of $\mathrm{PBC}$ to the reservoir supplying drinking water, ${ }^{20}$ there have been reports of geographical and seasonal clustering of cases, ${ }^{21}$ and there is a report of PBC occurring in a non-related nurse of a patient with PBC. ${ }^{7}$ One suggestion is that an agent may be bacterial - that is, Escherichia coli - as there is cross reactivity between $E$ coli antigens and anti-mitochondrial antibodies. ${ }^{27}$ In some studies a high prevalence of $E$ coli urinary tract infections has been found among patients with PBC. ${ }^{28}$ Whatever the nature of the agent it has always been apparent that there is a long incubation period between the exposure and manifestation of the disease. All our family pairs spent a considerable period of their lives together but presented at different stages of the disease and at different times and had not been living together for some time in the immediate past. Four pairs of mothers and daughters presented within five years of each other but the second case to present was not always at a more advanced stage of the disease. Indeed the daughter in pair no 2 presented 17 years after her mother and with stage I disease. It is noteworthy that we did not find any case of PBC occurring in non-related family members. The case of PBC in a close contact of a patient did have a family history of autoimmune disease. ${ }^{7}$

In this series all the daughters presented at a younger age than their mothers. This may be partly because of increased awareness of the disease and the greater availability of screening nowadays leading to more being found with asymptomatic disease at an earlier age. Many of the daughters, however, presented either before their mothers or had a more rapid disease progression. The daughter who had a transplant and the daughter who has died were younger than any of the mothers at death or transplantation. In addition, the other three daughters with symptomatic disease became symptomatic at a younger age than their respective mothers. Interestingly, Tong et al found the same phenomenon, where the daughter was more severely affected than her mother. ${ }^{5}$

1 Walker JG, Bates D, Doniach D, Ball PAJ, Sherlock S. Chronic liver disease and anti-mitochondrial antibodies. A family study. $B M \mathcal{F} 1972 ; 1: 146-8$.

2 Klatskin G, Kantor FS. Mitochondrial antibody in primary biliary cirrhosis and other diseases. Ann Intern Med 1972; 77: 533-41.

3 Chohan MR. Primary biliary cirrhosis in twin sisters. Gut 1973; 14: 213-4.
4 Galbraith RM, Smith M, MacKenzie RM, Tee DE, Doniach D, Williams R. High prevalence of seroimmunologic abnormalities in relatives of patients with chronic active hepatitis or primary biliary cirrhosis. Clin Exp active hepatitis or primary

5 Tong MJ, Nies KM, Reynolds TB, Quismorio FP. Immunological studies in familial primary biliary cirrhosis. Gastroenterology 1976; 71: 305-7.

6 Fagan EA, Williams R, Cox S. Primary biliary cirrhosis in a mother and daughter. BMF 1977; 2: 1195.

7 Douglas JG, Finlayson NDC. Are increased individual susceptibility and environmental factors both necessary for the development of primary biliary cirrhosis? $B M \mathcal{F} 1979$; 2: 419-20.

8 Jaup BH, Zettergren LSW. Familial occurrence of primary biliary cirrhosis associated with hypergammaglobumlinemia in descendents: a family study. Gastroenterology 1980; 78: $549-56$.

9 Kato Y, Suzuki K, Kumagai M, Nishimimura A, Miyamora H, Kobayashi K. Familial primary biliary cirrhosis. $N$ Engl f Med 1974; 290: 63-9.

10 Cales P, Calot M, Vogt Jj, Iksman F, Cassigneul J, Vinel JP, et al. Familial autoimmune pathology comprising two cases of primary biliary cirrhosis. Gastroenterol Clin Biol 1983; 7: 777-84.

11 James SP, Jones EA, Schfer DF, Hoofnagle JH, Varma RR, Strober W. Selective immunoglobulin deficiency associated with primary biliary cirrhosis, in a family with liver disease. Gastroenterology 1986; 90: 283-8.

12 Chiaranti E, Smorlesi C, Chieca R, Moscarella S, Pasaleva A, Berg PA, et al. Familial immunological disorders and primary biliary cirrhosis. Ital $\mathcal{f}$ Gastroenterol 1987; 19: primary

13 Chalmers EA, Chan A, Lam DC, Holden RJ, Fitzsimons EJ. Familial PBC and autoimmune thrombocytopenia. Scott Med f 1987; 32: 152

14 James OFW, Myszor M. Epidemiology and genetics of primary biliary cirrhosis. In: Popper H, Schaffner F, eds. Progress in liver disease. Vol 9. London: WB Saunders, 1990: 523-37.

15 Manns MP, Bremm A, Schneider PM, Notghi A, Gerken G, Prager-Eberle M, et al. HL DRw8 and complement C4 deficiency as risk factors in primary biliary cirrhosis. Gastroenterology 1991; 101: 1367-73.

16 Tsuji H, Koichiro M, Kimihiro A, Fujishima M. Familial primary biliary cirrhosis associated with impaired concanavalin A induced lymphocyte transformation in relatives. Dig Dis Sci 1992; 37: 353-60.

17 Harada N, Dohmen K, Itoh H, Ohshima T, Yamamoto H, Nagano $\mathrm{M}$, et al. Sibling case of primary biliary cirrhosis associated with polymyositis, vasculitis and Hashimoto's thyroiditis. Intern Med 1992; 31: 289-93.

18 Bach N, Schaffner F. Prevalence of primary biliary cirrhosis in family members of affected patients. Gastroenterology 1991; 102: A776.

19 Miller KB, Sepersky RA, Brown KM, Goldenberg MK, Kaplan MM. Genetic abnormalities of immunoregulation in primary biliary cirrhosis. $\mathrm{Am} f \mathrm{Med} 1983$; 75: $75-80$.

20 Triger DR. Primary biliary cirrhosis, an epidemiological study. $B M F$ 1980; $281: 775$.

21 Hamlyn AN, Macklon AF, James O. Primary biliary cirrhosis geographical clustering an aymptomatic onset cirrhosis geographical clustering

22 Briggs DC, Donaldson PT, Hayes P, Welsh KI, Williams R. A major histocompatibility complex Class III allotype (C4B2) associated with primary biliary cirrhosis. Tissue Antigens 1987; 29: 141-5.

23 Underhill J, Donaldson P, Bray G, Doherty D, Portman B, Williams R. Susceptibility to primary biliary cirrhosis is associated with the HLA DR8`DQB10402 haplotype. Hepatology 1992; 16: 1404-8.

24 Fugger L, Morling N, Ryder LP, Platz P, Georgsen J, Jakobsen BK, et al. Nco I RFLP of tumour necrosis factor alpha region in primary biliary cirrhosis in healthy Danes. Scand f Immunol 1989; 30: 185-9.

25 Rugger L, Morling N, Ryder LP, Jakobsen BK, Andersen V, Oxholm P, et al. RFLP of two HLA B associated transcript genes in five autoimmune disease. Hum Immunol script genes in five

26 ten Wolde S, Breedveld FC, De Vries RR, D'Amoro J, Rubenstein P, Schreuder GMTh, et al. Influence of noninherited maternal HLA antigens on occurrence of rheumatoid arthritis. Lancet 1993; 341: 200-2.

27 Stemerowicz R, Moller B, Rodloff A, Freudenberg M, Hopf $\mathrm{U}$, Wittenbrink $\mathrm{C}$, et al. Are anti-mitochondrial antibodies in primary biliary cirrhosis induced by $\mathbf{R}$ (rough) mutants of Enterbacteriaceae? Lancet 1988; ii: 1166-70.

28 Burroughs AK, Rosenstein IJ, Epstein O, Hamilton-Miller JMT, Brumfitt W, Sherlock S. Bacteriuria and primary biliary cirrhosis. Gut 1984; 25: 133-7. 